\title{
Medicine in Shakespearean Plays: Compilation of Descriptions of Clinical Features and Pathophysiology
}

\author{
Nasir Abdul Latif Sarwani, (Ph.D.), Durjoy Kumar Shome, (MD, FRCPath), Henry James, (MD, DM), \\ Manoj Chakravarty, (MD) (Corresponding Author) \\ Institution: College of Medicine \& Medical Sciences, Arabian Gulf University, Bahrain \\ Email of Corresponding author: manojc@agu.edu.bh
}

\begin{abstract}
William Shakespeare's plays provide an invaluable compendium of medical terminology in the form of brief to detailed descriptions of clinical features and pathophysiology of various medical conditions. Shakespeare's ability to describe dysfunctions of the human body and mind is astounding and has remained so for almost four centuries. The afflictions appear in the characters of kings, princes' and commoners in his plays and their clinical features described in verse are more or less true even to this day. The aim of this study is to present a comprehensive compilation of medical afflictions from Shakespearean plays in alphabetical order containing verses that specifically depict clinical features, pathophysiology of medical conditions and medical ethics, and to provide short clinical explanations of relevance of passages in modern times as appropriate. Most passages do not reflect on the clinical conditions of actual patients, but deal with figurative expressions, drawn from clinical relevance in medicine during the Shakespearean era and used figuratively by the bard to illustrate those expressions through characters in the plays.
\end{abstract}

Keywords: Shakespeare and Medicine, History of Medicine, Clinical features, Symptomatology, Pathophysiology

DOI: $10.7176 / \mathrm{JHMN} / 62-16$

Publication date:May $31^{\text {st }} 2019$

\section{Introduction}

Shakespeare's literary legacy of plays is so informative, intricate and stimulating, that even after four centuries, they are regarded with conspicuous veneration. For modern audiences who are either professionals in the medical field or have an interest in medicine, Shakespearean plays are a portal on human afflictions, and the figurative descriptions made by the bard in his plays at a time when the term 'medical science' was oxymoronic and people believed disease was a punishment for sinful behaviour and when afflictions on health were perceived to be the result of movement of stars and the planets, have indeed been most ingenious. Whatever the cause, virtually everyone agreed at the time that these maladies were triggered by an imbalance in the four vital fluids in the body - blood, phlegm, black bile, and yellow bile called "humours" (Latin word for liquids), and that these fluids controlled health and behaviour by the subtleties of their overall balance in the body.

Shakespearean plays convey a profound insight into scientific knowledge and it is in this regard noteworthy, that it would indeed be very unusual, had the issue of health and disease found no place in his literary collection. Shakespeare was born in 1564, just about the time medicine was moving out of the ivory towers of the medieval world. The low status barber-surgeon was becoming a respected medical practitioner with a new arsenal of techniques for dealing with wounds and illness ${ }^{13}$. Shakespeare had lived in London in the early 1590 s. The city at that time was a prolific breeding ground of pestilence because of profound unsanitary conditions, and hygiene was almost a non-entity and consequently, Shakespeare's London was the embodiment of filth. It is important to state in context that caution is required while attempting to interpret Shakespeare's description of clinical features in the light of modern medicine where his descriptions are at best figurative albeit the similarity to the modern medical view, and diseases including clinical features are used metaphorically as a means to project the Bard's superlative genius.

This is by no means the first study looking into the description of health and medicine in Shakespearean plays. The earliest reference in context is from $1865{ }^{16}$ which documents a limited selection of passages out of which only a few, truly reflect description of clinical features or their underlying mechanisms. This was followed almost a century later by brief commentaries from Kail ${ }^{12}$ regarding a compilation of extracts presenting descriptions of mental illness in Shakespearean plays; by Goens \& Gheeraert ${ }^{8}$ regarding extracts dealing with skin infections and Owen ${ }^{14}$, regarding description of the circulation of blood. Articles by Andreasen ${ }^{3}$ dealing with psychiatric 
diagnosis in Shakespearean tragedies, Kail ${ }^{10}{ }^{11}$ regarding a compilation of mental illness, and Fogan's ${ }^{6}$ excellent compendium on neurological descriptions in Shakespearean plays are on record. Descriptions of surgical conditions and techniques have been addressed too ${ }^{7}$, and pathophysiological references related specifically to neurological disorders in Shakespearean plays have been described by Chakravarty ${ }^{4}$.

As no detailed study of descriptions of clinical features (symptoms and signs) or their underlying pathophysiology of all possible medical conditions from Shakespearean plays is currently available since the preliminary and brief study by Stearns ${ }^{16}$, this study is hence aimed at achieving the above at a comprehensive level. Descriptions of verses from the plays are documented with explanations of medical conditions ${ }^{5}$ but lack the element of detailed description of symptomatology and pathophysiological relationships.

This article lists 133 selected passages that have been presented under 33 headings enumerated alphabetically dealing with specific medical conditions. The number of passages showing the poet's acquaintance with the art of medical science bear witness to the bard's extensive depth of knowledge in the area, and reflect expressions built from facts related to medical symptomatology, underlying mechanisms, ethics and management guidelines used figuratively by the characters in the plays. Brief explanations for each reference has been annotated under each quoted passage to provide a meaningful and scientific relationship to present day clinical conditions thus making the treatise more succinct.

All quoted passages have been selected from "The Complete Signet Classic Shakespeare"; Harcourt Brace Jovanovich Edition, 1972, ISBN: 0-15-512610-5.

\section{Discussion}

\subsection{Abortion}

1. Richard III, Act I, Scene II,

If ever he have child, abortive be it, 21

Prodigious, and untimely brought to light,

Whose ugly and unnatural aspect

May fright the hopeful mother at the view, 24

The reference to the anomalous physical features of the aborted foetus have been described.

\subsection{Age related changes}

2. Macbeth, Act I, Scene I, (hirsutism)

Upon her skinny lips. You should be women, 45

And yet your beards forbid me to interpret

That you are so. 47

The reference to Hirsutism as a result of altered hormonal function in post-menopausal women has been stated.

3. The Tempest, Act IV, Scene I

Sir, I am vex'd; 158

Bear with my weakness; my old brain is troubled;

Be not disturb'd with my infirmity 160

'Troubled old brain' is indicative of the symptomatology of senile dementia.

4. King Lear, Act I, Scene I,

Goneril- You see how full of changes his age is; the observation we 287

have made of it hath not been little. He always loved our sister most;

and with what poor judgment he hath now cast her off appears

too grossly.

Regan- Tis the infirmity of his age; yet he hath ever but slenderly known himself.

Goneril- The best and soundest of his time hath been but rash; then

Must we look from his age to receive not alone the imperfections of

long engraffed condition, but therewithal the unruly waywardness that 
infirm and choleric years bring with them 298

The effect of senile dementia with its severity in described in this scene.

5. King Lear, Act I, Scene IV,

Into her womb convey sterility, 280

Dry up in her the organs of increase,

And from her derogate body never spring

A babe to honor her. 283

Let it stamp wrinkles in her brow of youth, 286

With cadent tears fret channels in her cheeks 287

The incapacitated status in terms of absence of fertility with growing age has been alluded to.

6. $\quad$ King Lear, Act I, Scene III,

Idle old man, 17

That still would manage those authorities

That he hath given away! Now by my life,

Old fools are babes again, and must be us'd

With checks as flatteries, when they are seen abus'd. 20

The old, struck with the infirmity of senility behave as babies in their pattern of behaviour.

7. King Henry The Fourth, Part Two, Act I, Scene II,

Do you set down your name in the scroll of youth, that are written 180

down old with all the characters of age ? Have you not a moist eye, a

dry hand, a yellow cheek, a white beard, a decreasing leg, an

increasing belly? Is not your voice broken, your wind short, your

chin double, your wit single, and every part about you blasted with

antiquity, and will you yet call yourself young? 187

Every feature described correlates perfectly with specific age-related changes, be it the eyes reflecting corneal dryness (xerophthalmia) with tearing, the wrinkled face and hands, the trunk, the pot belly and the waning intellect.

8. King Henry The Fifth, Act V, Scene II,

A good leg will fall; a straight back will stoop; a black beard will 161

turn white; a curl'd pate will grow bald; a fair face will wither; a

full eye will wax hollow. 164

The features describe the age-related effects of reduced musculoskeletal coordination, advanced osteoarthrosis of the spine leading to kyphosis along with sunken eyes (enophthalmos).

9. King Henry The Sixth, Part One, Act II, Scene V,

Kind keepers of my weak decaying age, 1

Let dying Mortimer here rest himself.

Even like a man new haled from the rack,

So fare my limbs with long imprisonment;

And these grey locks, the pursuivants of death,

Nestor-like aged in an age of care,

Argue the end of Edmund Mortimer.

These eyes, like lamps whose wasting oil is spent,

Wax dim, as drawing to their exigent;

Weak shoulders, overborne with burdening grief, 
And pithless arms, like to a withered vine

That droops his sapless branches to the ground.

Yet are these feet, whose strengthless stay is numb,

Unable to support this lump of clay,

Swift-winged with desire to get a grave,

As witting I no other comfort have. 16

Age-related physical features of senility have been described to characterize enophthalmos, wasting of proximal appendicular musculature that are unable to support a lifeless trunk has been made apparently insensitive to normal sensory stimuli.

10. King Henry The Sixth, Part One, Act IV, Scene V,

That Talbot's name might be in thee revived 3

When sapless age and weak unable limbs

Should bring thy father to his drooping chair. 5

This description repeats the age-related degenerative features of decreased musculoskeletal functions with kyphosis of the spinal column.

11. Much Ado About Nothing, Act III, Scene V,

A good old man, sir, he will be talking; as they say "when the age is 33

in the wit is out". God help us, it is a world to see. 34

The verse refers to the direct relationship between old age and dwindling cerebral functions of intellect.

12. As You Like It, Act II, Scene II,

Though I look old, yet I am strong and lusty, 47

For in my youth I never did apply

Hot and rebellious liquors in my blood,

Nor did not with unbashful forehead woo

The means of weakness and debility;

Therefore my age is as a lusty winter. 52

Age-related general debility has been described here.

13. Hamlet, Act II, Scene II,

That old men have gray beards, that their faces are 198

wrinkled, their eyes purging thick amber and plum-

tree gum, and that they have a plentiful lack of wit'

together with most weak hams. 201

Repeated mention of loss of skin turgor, reduced intellect and muscle weakness is depicted in this verse.

\subsection{Alcohol and effects}

14. The Merchant of Venice, Act I, Scene I,

With mirth and laughter let old wrinkles come 80

And let my liver rather heat with wine

Than my heart cool with mortifying groans.

Why should a man whose blood is warm within

Sit like his grandsire cut in alabaster,

Sleep when he wakes? And creep into jaundice 85

The deleterious effect of alcohol on the liver is mentioned here along with the fact that an ill-functioning liver is related to icterus (jaundice). Alabaster (fine white material derived from limestone) refers to the profound degree of paleness of the face (anaemia) which is a feature of chronic alcoholism. 
15. King Henry the Fourth, Part Two, Act II, Scene IV,

I'faith, sweetheart, me thinks now you are in an excellent good 22

temporality. Your pulsidge beats as extraordinarily as heart would desire; and

your color, I warrant you, is as red as any rose, in good

truth, la! But, i'faith, you have drunk too much canaries: and that's a

marvelous searching wine, and it perfumes the blood ere one can say

"What's this?" 28

The effect of alcohol on sympathetic stimulation causing tachycardia and peripheral vasodilatation is stated in the verse.

16. King Henry the Fourth, Part Two, Act IV, Scene III,

There's never none of these demure boys come to any proof; for thin 90

drink doth so over-cool their blood, and making many fish meals,

that they fall into a kind of male green-sickness; and then, when they

marry, they get wenches. They are generally fools and cowards-

which some of us should be too, but for inflammation. A good

sherris-sack hath a twofold operation in it. It ascends me into the

brain; dries me there all the foolish and dull and crudy vapours which

environ it; makes it apprehensive, quick, forgetive, full of nimble,

fiery, and delectable shapes; which delivered o'er the voice, the

tongue, which is the birth, becomes excellent wit.

The second property of your excellent sherris is the warming of

the blood, which, before cold and settled, left the liver

white and pale, which is the badge of pusillanimity and cowardice.

But the sherris warms it and makes it course from the inwards to the

parts extremes. It illumineth the face, which as a beacon gives

warning to all the rest of this little kingdom, man, to arm, and then the

vital commoners and inland petty spirits muster me all to their

captain, the heart, who, great and puffed up with this retinue, doth any

deed of courage, and this valor comes of sherris. 114

The above verse states the side effect of nausea and the autonomic effect of erectile dysfunction even in young adults. It goes on to elaborate other deleterious functions on the central nervous system wherein the features of dulling of higher functions to the extent of inducing hallucinogenic symptoms. The effect on warming of the blood due to increased peripheral circulation is mentioned and so are the flushing effects of vasodilatation on the face and readying the body for action by stimulating cardiac functions (fight and flight phenomenon).

17. King Henry the Fifth, Act III, Scene V,

Can sodden water, 18

A drench for sur-rein'd jades, their barley broth,

Decoct their cold blood to such valiant heat?

And shall quick blood, spirited with wine, seem frosty? 22

Another example of the increased effect on the sympathetic system has been described above.

18. Troilus and Cressida, Act V, Scene I,

I'll heat his blood with Greekish wine tonight, 1

Which with my scimitar I'll cool to-morrow. 2 
Activation of the sympathetic system to activate the mind only to be pacified through the action of the sword.

19. Antony and Cleopatra, Act I, Scene II,

I had rather heat my liver with drinking 25

The deleterious effect of alcohol on the liver is stated.

20. Antony and Cleopatra, Act II, Scene VII,

Till that conquering wine hath steep'd our sense 108

In soft and delicate Lethe 109

Come thou monarch of the vine 114

Plumpy Bacchus with pink eyne!

In thy fats our cares be drown'd,

With thy grapes our hairs be crown'd.

Cup us till the world go round 118

You see we have burnt our cheeks: strong Enobarb 123

Is weaker than the wine, and mine own tongue

Splits what it speaks. The wild disguise hath almost

Antick'd us all 125

The overpowering effect of alcohol causing the "lethe" indicates a state of oblivion or even death. The verse draws the association of drinking to reddening of the eyes and deposition of fat in the body (increased calories). The grape as wine is a notable sign of pleasure, where luxury, indulgence and sensuality are ubiquitous. "Mine own tongue splits what it speaks" illustrates the state of illusion to the effects of wine upon his ability to articulate and deceives him of his exposure to inebriety.

21. Twelfth Night, Act V, Scene I,

O he's drunk, Sir Toby, an hour agone; his eyes were set at eight i' th'

morning. 197-198

The effect of consuming too much alcohol is related to causation of ophthalmoplegia where the coordination of extraocular muscles is lost and the eyes are squinted (convergent strabismus).

22. Macbeth, Act I, Scene VII,

Was the hope drunk 35

Wherein you dress'd yourself? Hath it slept since,

And wakes it now to look so green and pale at what it did so freely 37

The lofty desire for hope is being compared to drunkenness and the severity is compared to the hangover that follows such a binge where the person swoons and nauseates (looks so green as in sea-sickness) and the face is robbed of its blood supply thus appearing pale.

23. Macbeth, Act I, Scene VII,

Will I with wine and wassail so convince 64

That memory, the warder of the brain,

Shall be a fume, and the receipt of reason

A limbek only 67

The effect of too much alcohol on suppression of memory which appears to leave the body as vapours from a retort (limbek) has been described.

24. Macbeth, Act II, Scene III,

And drink sir, is a great provocator of three things. 24

Macduff- What three things does drink especially provoke?

Porter- Marry, sir, nose-painting, sleep, and urine. Lechery, sir, it provokes and 
unprovokes: it provokes the desire, but it takes away the performance. Therefore, much drink may be said to be an equivocator with lechery: it makes him, and it mars him; it sets him on, and it takes him off; it persuades him, and disheartens

him; makes him stand to, and not stand to; in conclusion, equivocates him in a

sleep, and, giving him the lie, leaves him. 36

The effects of alcohol on the body has been described in detail. It causes nasal flush, induces sleep and makes one lose control of the urinary bladder leading to incontinence. It provokes lewd and lustful behavior (lechery). It stimulates libido but causes erectile dysfunction.

25. Timon of Athens, Act I, Scene II,

If I were a huge man I should fear to drink at meals, 48

Lest they should spy my windpipe's dangerous notes.

Great men should drink with harness on their throats. 51

Getting drunk sways the head in extension while a person is sitting thereby exposing the trachea which is easy to reach with a knife for example. The midline anatomy of the neck is thus exposed.

\section{Coriolanus, Act V, Scene I,(Hangover)}

He was not taken well; he had not dined. 50

The veins unfilled, our blood is cold, and then

We pout upon the morning, are unapt

To give or to forgive; but when we have stuffed

These pipes and these conveyances of our blood

With wine and feeding, we have suppler souls

Than our priestlike fasts. 55

The relationship here is drawn between the temperament in the unfed versus the fed states. In the unfed state the circulation is sluggish and the mind is unable to concentrate and even judge properly. In the fed state the circulation is adequate and judgment is better.

\subsection{Ano-rectal conditions}

27. All's well that ends well, Act I, Scene I,

Bertram- What is it my good lord, the King languishes of? 34

Lafeu- A fistula my lord 35; and continues in Act I, Scene II as

King Lend me an arm. The rest have worn me out 73

With several applications: nature and sickness

Debate it at their leisure 75

The suffering and lack of proper treatment of anorectal fistula despite repeated application of medication, makes the cure debatable.

\subsection{Apolplexy}

\section{Coriolanos, Act IV, Scene V,}

Peace is a very apoplexy, lethargy; mull'd, deaf, sleepy, insensible; 235

a getter of more bastard children than war's a destroyer of men 237

Peace is akin to a state of speechlessness, deafness and sleepy nature that is insensitive to normal stimulus but sparks the libido; thus, more bastard children are born during peacetime than men dying in war.

29. King Henry The Fourth, Part Two, Act I, Scene II,

And I hear, moreover, his highness is fall'n into the same whoreson apoplexy. 108

This apoplexy, as I take it, is a kind of lethargy, an't please your lordship, a kind 112

of sleeping in the blood, a whoreson tingling. 114, and continues 
It hath it original from much grief, from study, and perturbation of the brain. I 116

have read the cause of his effects in Galen; it is a kind of deafness. 118

The clinical features of a stroke are described herein which include a state of inaction, and sensory disturbances including loss of hearing (brainstem lesion). It is the result of disturbances in the brain.

30. Richard II, Act II, Scene III,

O, then, how quickly should this arm of mine, 102

Now a prisoner to the palsy, chastise thee, 103

The paralysing effect of monoplegia or possibly hemiplegia have been referred to.

31. Richard III, Act III, Scene IV,

Look how I am bewitched. Behold, mine arm 67

Is like a blasted sapling withered up; 68

The long term effect of muscle wasting following a stroke and replacement by fibrosis has resulted in a rigid ('withered') extremity.

32. Hamlet, Act III, Scene IV,

Sense sure you have, 72

Else could you not have motion, but sure that sense

Is apoplexed, for madness would not err,

Nor sense to ecstasy was ne'er so thrilled

But it reserved some quantity of choice

To serve in such a difference. What devil was't

That thus hath cozened you at hoodman-blind?

Eyes without feeling, feeling without sight,

Ears without hands or eyes, smelling sans all,

Or but a sickly part of one true sense

Could not so mope. 82

The suppression of the special senses resulting from a stroke are being described.

\subsection{Back Injury}

33. The Tempest, Act III, Scene I,

Miranda- I'll bear you logs the while; pray give me that; 23

I'll carry it to the pile

Ferdinand- No, precious creature;

I'd rather crack my sinews, break my back 26

The relationship between injured muscles and back pain has been described here, and it is known that reflex spasm of muscles (muscle injury) resulting from vertebral injury, is a major cause of back pain.

34. Romeo and Juliet, Act III, Scene V.5

Lord, how my head aches! what a head have I! 43

It beats as it would fall in twenty pieces. 44

My back o' t' [on the] other side,- - O, my back, my back! 45

Beshrew your heart for sending me about, 46

To catch my death with jaunting up and down! 47

The relationship between a pulsating (throbbing) headache and back pain related to excessive physical activity has been described.

\subsection{Binocular vision}




\section{King Lear, Act I, Scene V,}

Fool- Thou canst tell why one's nose stands i' th' middle on's 19

face?

Lear- No

Fool- Why, to keep one's eyes of either side's nose,

That what a man cannot smell out, he may spy into. 23

The reference here is made to the fact that both eyes and the nose being organs of special senses, the sense of smell is less lateralizing (functional) while that of vision is far more developed and the eyes being located apart, offer a greater depth of vision (stereoscopic) and thus accuracy.

\subsection{Blood / Circulation}

36. Coriolanus, Act I, Scene I,

That I receive the general food at first 133

Which you do live upon; and fit it is,

Because I am the storehouse and the shop of the whole body.

But if you do remember,

I send it through the rivers of your blood,

Even to the court, the heart, to th' seat o' th' brain;

And, through the cranks and offices of man,

The strongest nerves and small inferior veins

From me receive that natural competency whereby they live; 143

This verse states the functions of the systemic circulation and relates the fact that blood goes back to the heart and from thence is pumped to the brain and this circulation provides all the necessary ingredients (nutrition) for the body to sustain itself.

37. Troilus and Cressida, Act V, Scene 1,

With too much blood and too little brain these two may run mad; 49

but, if with too much brain and too little blood they do, I'll be a

curer of madmen. 51

The reference is with respect to a state of hyper-dynamic systemic circulation with insufficient blood supply to the brain in a diseased state that can reduce mental functions. Conversely, increased cerebral function can be sustained with a reduction in cerebral blood flow (auto-regulation).

38. Henry VI, Part Two, Act III, Scene II,

See how the blood is settled in his face. 160

Oft have I seen a timely parted ghost,

Of ashy semblance, meager, pale, and bloodless,

Being all descended to the laboring heart,

Who in conflict that it holds with death,

Attracts the same for aidence 'gainst the enemy;

Which with the heart there cools, and ne'er returneth

To blush and beautify the cheek again. 167

The verse describes a state of shock where the blood is diverted to the heart due to sympathetic response leaving the face ashen, lifeless and ghostly.

39. Romeo and Juliet, Act IV, Scene I,

When presently through all thy veins shall run 95

A cold and drowsy humor; for no pulse 
Shall keep his native progress, but surcease;

No warmth, no breath, shall testify thou livest;

The roses in thy lips and cheeks shall fade

To wanny ashes, 100

The effects of a certain unknown potion have been described here that slows the circulation and makes the vital signs including the pulse to become imperceptible as if to mimic a state of death.

40. King John, Act III, Scene III,

Or if that surly spirit, melancholy, 52

Had baked thy blood and made it heavy, thick,

Which else runs tickling up and down the veins,

Making that idiot, laughter, keep men's eyes

And strain their cheeks to idle merriment. 56

This verse refers to the relationship between melancholy (depression) and the vascular effects of inactivity causing slowing of the circulation. The reduced circulation to the brain in consequence, results in altered behaviour which in this case has been described as idiotic.

41. Twelfth Night, Act I, Scene I,

How will she love when the rich golden shaft 36

Hath killed the flock of all affections else

That live in her; when liver, brain, and heart,

These sovereign thrones, are all supplied and filled 39

Each one of the three organs has been referred to as precious kingdoms which in context states the functional importance of the circulation in these organs for maintaining a healthy state of the mind and emotions which can be affected if these were to be injured figuratively as in this case by Cupid's golden arrow.

\subsection{Bones \& Joints}

42. Measure For Measure, Act I, Scene II,

Lucio- Nay, not as one would say, healthy, but so 56

sound as things that are hollow. Thy bones are hollow;

impiety has made a feast of thee.

First Gentleman- How now! Which of your hips

has the most profound sciatica? 60

This verse describes the features of bone (cortical) thinning (osteopenia) that is associated with degenerative disease affecting the spine (sciatica).

43. Troilus and Cressida, Act I, Scene II,

He hath the joints of everything, 27

but everything so out of joint that he is a gouty

Briareus, many hands and no use, or purblind Argus,

all eyes and no sight. 30

The verse states the fact that in spite of having joints that help the hands and fingers to move, the affliction has so affected these small joints that they present the features of gouty (rheumatoid) arthritis that also affects vision through xerophthalmia (corneal dryness).

44. Troilus and Cressida, Act V, Scene III,

And I have a rheum in mine eyes too, 104

and such an ache in my bones that unless a man were curs'd,

I cannot tell what to think on't. 106 
Ocular inflammation occurs in patients with systemic rheumatic disease. After diagnosis, ocular inflammation can mark the severity of the systemic condition ${ }^{1}$. The most common eye-related symptom of rheumatoid arthritis is xerophthalmia. More rarely, rheumatoid arthritis can cause inflammation in the white part (sclera) of the eyes, resulting in redness and pain.

45. Romeo and Juliet, Act II, Scene V,

Are you so hot? Marry, come up, I trow; 63

Is this the poultice for my aching bones?

Henceforward, do your messages yourself. 65

This verse states the importance of physiotherapy and its benefits on bones and joints.

46. Hamlet, Act III, Scene II,

No, let the candied tongue lick absurd pomp, 60

And crook the pregnant hinges of the knee. 61

The morphology of the knee has been depicted as the "hinge" variety, and describing its functions as very potent (significant) but which is affected by disease due to an uncontrolled diet.

47. King Henry The Fourth, Part Two, Act I, Scene I,

And as the wretch whose fever-weak'ned joints, 140

Like strengthless hinges, buckle under life 141

This description befits the state of the body in Rheumatoid arthritis where fever and joint involvement causes loss of stability in the joints that make them functionless and thus prone to deformities.

48. As You Like It, Act III, Scene II,

With a priest that lacks Latin and a rich 319

man that hath not the gout; for the one sleeps easily

because he cannot study, and the other lives merrily

because he feels no pain; the one lacking the burden

of lean and wasteful learning, the other knowing no

burden of heavy tedious penury. 324

The comparison here is between the lifestyle of a religious scholar and the relaxed life of the rich who in the absence of hard work do not suffer profound pain in the affliction with gout.

\subsection{Breathing}

49. Troilus and Cressida, Act IV, Scene V,

Thou, trumpet, there's my purse. 6

Now crack thy lungs and split thy brazen pipe.

Blow, villain, till thy sphered bias cheek

Outswell the colic of puffed Aquilon!

Come, stretch thy chest, and let thy eyes spout blood; 10

The verse exemplifies the effects of bronchoconstriction that alters the voice (Wheeze and Stridor), pursing of the lips, barrel chest deformity, and exophthalmos which are all the physical manifestations of chronic obstructive lung disease.

50. Timon of Athens, Act V, Scene IV,

Have wander'd with our traversed arms, and breathed 7

Our sufferance vainly. Now the time is flush,

When the crouching marrow, in the bearer strong,

Cries of itself, No more. Now breathless wrong

Shall sit and pant in your great chairs of ease, 
And pursy insolence shall break his wind

With fear and horrid flight. 13

The increased sympathetic stimulation as a result of increased physical activity makes one hungry for breath (breathlessness).

\subsection{Burns}

51. Timon of Athens, Act V, Scene I,

Thou sun that comforts, burn! Speak and be hanged. 131

For each true word a blister, and each false

Be as a cauterizing to the root o' th' tongue 132

The figurative effect of uncontrolled speech has been likened to a thermal injury that blisters the tongue.

\subsection{Castration (Effects - Somatic and psychological)}

52. Antony and Cleopatra, Act I, Scene V,

Cleopatra- I take no pleasure 9

In aught an eunuch has: 'tis well for thee

That being unseminared, thy freer thoughts

May not fly forth of Egypt. Hast thou affections?

Mardian- Yes, gracious madam.

Cleopatra- Indeed?

Mardian- Not in deed, madam; for I can do nothing

But what indeed is honest to be done:

Yet I have fierce affections, and think

What Venus did with Mars. 18

The verse states clearly that the physical disablity of being a eunuch does not have any reduction in the 'libido' but incapacitates the physical ability due to castration.

\subsection{Central nervous system}

53. Love's Labor's Lost, Act IV, Scene II,

These are begot in the ventricle of memory, 69

nourished in the womb of pia mater, and delivered

upon the mellow of occasion. 71

The explanation that appears here is the supportive and protective role of the ventricles (and CSF) and the meningeal layer of pia mater between which lie the frontal and temporal cortices including the hippocampus that are associated with memory and higher cognitive functions.

\section{Love's labor's Lost, Act IV, Scene III,}

Lives not alone immured in the brain, 325

But with the motion of all elements,

Courses as swift as thought in every power,

And gives to every power a double power

Above their functions and their offices. 329

This stanza explains the authoritative role of the brain on the direct activation of all motor functions by transfer of energy ("motion of all elements').

55. Timon of Athens, Act I, Scene II,

The five best senses 123

Acknowledge thee their patron, and come freely 124

To gratulate thy plenteous bosom. Th' ear 125 
Taste, touch, all, pleased from their table rise; 126

The feeling of fulfillment as a result of all the special senses working normally has been alluded to here.

56. Antony and Cleopatra, Act IV, Scene VIII,

ha 'we 20

A brain that nourishes our nerves, and can 21

Get goal for goal for youth. 22

The connection and control of the brain on the peripheral nervous system is described here.

\subsection{Congenital deformities}

57. Henry VI, Part Three, Act III, Scene II,

Why, love forswore me in my mother's womb: 153

And, for I should not deal in her soft laws, 154

She did corrupt frail nature with some bribe, 155

To shrink mine arm up like a withered shrub; 156

To make an envious mountain on my back, 157

Where sits deformity to mock my body; 158

To shape my legs of unequal size; 159

To disproportion me in every part, 160

The verse describes the possible cause of some teratogenic influence ("She did corrupt frail nature with some bribe") that causes a widespread skeletal malformations.

58. King Lear, Act III, Scene IV,

He gives the web and the pin, squints the eye, and makes 115

the harelip; mildews the white wheat, and hurts the

poor creature of the earth." 117

The congenital defects affecting the lips (cleftlip), face and eyes (hypertelorism) have been described in this verse that correlate with the study by Moss ${ }^{14}$.

59. King John, Act III, Scene I

If thou ... wert grim, 45

Ugly and slanderous to thy mother's womb 46

Full of unpleasing blots and sightless stains, 47

Lame, foolish, crooked, swart, prodigious, 48

Patch'd with foul moles and eye-offending marks, 49

I would not care, I then would be content 50

For then I should not love thee. 51

The significance of port wine stain and its relationship with congenital features of mental illness and weakness of a part of the body is stated in this verse. An uncommon disorder known as Sturge-Weber syndrome is associated with port-wine stain along with defects in the brain that can lead to ocular abnormalities, mental retardation, fitting, one-sided weakness of the body (hemiplegia) or other neurological signs and symptoms later in life ${ }^{17}$.

2.15 Death

60. Romeo and Juliet, Act IV, Scene V,

Lady.Capulet- Alack the day, she's dead, she's dead, she's dead! 24

Capulet- Ha! Let me see her. Out, alas! She's cold,

Her blood is settled, and her joints are stiff;

Life and these lips have long been separated.

Death lies on her like an untimely frost 
Upon the sweetest flower of all the field. 28

The effect of rigor mortis causing rigidity of the limbs (stiff joints) that confirms that death has ocurred some time ago has been described here.

61. King Lear, Act V, Scene III,

I know when one is dead and when one lives; 262

She's dead as earth. Lend me a looking-glass;

If her breath will mist or stain the stone,

Why, then she lives. 264

The absence of moisture on a mirror held close to the nostrils (cessation of breathing) is described as a sign of death.

62. Henry VI, Part Two, Act III, Scene II, (Medico-legal)

But see, his face is black and full of blood, 168

His eyeballs further out than when he lived,

Staring full ghastly like a strangled man;

His hair upreared, his nostrils stretched with struggling;

His hands abroad displayed, as one that grasped

And tugged for life, and was by strength subdued.

Look, on the sheets his hair, you see, is sticking;

His well-proportioned beard made rough and rugged,

Like to the summer's corn by tempest lodged.

It cannot be but he was murdered here:

The least of all these signs were probable. 178

The post-mortem signs of asphyxiation have been described here that confirm the cause of death.

63. Twelfth Night, Act IV, Scene II, (Post-mortem changes)

Nay, I'll ne'er believe a madman 'till I see his brains. 118

The reference is to the pathological changes in the cortex (cortical thinning and enlarged ventricles) that are associated with senile dementia.

64. Richard III, Act I, Scene II, (Post-mortem changes)

O gentlemen, see, see dead Henry's wounds 55

Open their congealed mouths and bleed afresh!

Blush, blush, thou lump of foul deformity,

For 'tis thy presence that exhales this blood

From cold and empty veins where no blood dwells. 59

The absence of bleeding from post-mortem wounds has been described here.

65. The Winter's Tale, Act III, Scene II,

I say she's dead; I'll swear 't, if word nor oath 201

Prevail not, go and see; if you can bring

Tincture or luster in her lip, her eye,

Heat outwardly or breath within, 204

The signs of death are very appropriately described here including paleness of the lips, drying and haziness of the cornea and loss of breathing.

66. Pericles, Prince of Tyre, Act III, Scene II, ( A physician named Cerimon says)

Death may usurp on nature many hours, 98 
And yet the fire of life kindle again 99

The overpress'd spirits. I heard 100

Of an Egyptian, that had nine hours lien dead, 101

Who was by good appliances recovered. 102

Moments later, he says

This queen will live: nature awakes; a warmth 110

Breathes out of her: she hath not been entranced 111

Above five hours: see how she gins [begins] to blow 112

Into life's flower again! 113

The physician does not believe that the wife of Pericle, Thaissa is dead and believes that she is in a state of catatonia or in a state of asystole that mimics death and after a lapse of a few hours, the person comes back to life.

\subsection{Dementia}

67. The Winter's Tale, Act IV, Scene IV,

Is not your father grown incapable 400

Of reasonable affairs? Is he not stupid

With age and alt'ring rheums? Can he speak, hear?

Know man from man? Dispute his own estate?

Lies he not bed-rid? And again does nothing

But what he did being childish? 404

Clinical signs of dementia are stated here that include inability to reason, stupidity, forgetfulness, inability to recognize faces and a host of ailments that make the person bed-ridden.

68. King Lear, Act I, Scene I,

Then must we look from his age to 295

receive not alone the imperfections of long in-grafted

condition, but therewithal the unruly waywardness

that infirm the choleric years bring with them. 298

Senile dementia not only exposes deeply-rooted bad habits, but also the unpredictable bad temper that comes with it.

69. King Lear, Act IV, Scene VII,

Pray, do not mock me: 59

I am a very foolish fond old man,

Fourscore and upward, not an hour more or less;

And, to deal plainly,

I fear I am not in my perfect mind.

Methinks I should know you and know this man,

Yet I am doubtful; for I am mainly ignorant

What place this is, and all the skill I have

Remembers not these garments, nor I know not

Where I did lodge last night. 67

Anxiety of not being in the right mind is a feature of senility. Inability to recognize people, to identify known places and even remember what clothes one wears or where one sleeps the previous night, are features of dementia.

2.17 Depression

70. Macbeth, Act V, Scene III, 
Doctor- Not so sick my lord， 37

As she is troubled with thick-coming fancies

That keep her from her rest.

Macbeth- Cure her of that.

Canst thou not minister to a mind diseased,

Pluck from the memory a rooted sorrow,

Raze out the written troubles of the brain,

And with some sweet oblivious antidote

Cleanse the stuffed bosom of that perilous stuff

Which weighs upon the heart? 44

Fanciful thinking, mind rooted in deep sorrow, and the affliction with a heavy heart are signs of clinical depression.

71. King Lear, Act IV, Scene VII,

Cordelia- How fares your majesty? 44

Lear- but I am bound 46

Upon a wheel of fire, that mine own tears

Do scald like molten lead. 48 and continues

Where have I been? Where am I? Fair daylight? 52

I am mightily abused. I should ev'n die with pity,

To see another thus. I know not what to say.

I will not swear these are my hands: let's see;

I feel this pin prick. Would I were assured

Of my condition. 57

The profundity of hopelessness and anguish in dementia are mentioned here. Endless pain and suffering akin to burns and scalds are described with a hint of dejection and loss of hope to continue living are also stated.

\subsection{Diet and disease}

72. Love's Labor's Lost, Act I, Scene I,

The mind shall banquet through the body pine. 25

Fat paunches have lean pates, and dainty bits

Make rich the ribs, but bankrout quite the wits. 27

The mind functions even in a state of hunger. Fat people are stupid, and delicious things makes the stomach larger, but intelligence and wit smaller. Relationship between obesity and foolishness is stated.

73. Measure For Measure, Act II, Scene I,

I telling you then, if you 106

be rememb'red, that such a one and such a one were

past cure of the thing you wot of, unless they kept

very good diet 109

The verse describes the usefulness of a good diet, for without it, even medication is useless.

74. Henry IV, Part 2, Act IV, Scene III

She either gives a stomach and no food 110

Such are the poor, in health —or else a feast

And takes away the stomach—such are the rich,

That have abundance and enjoy it not.

I should rejoice now at this happy news, 
And now my sight fails, and my brain is giddy.

O, me! Come near me, now I am much ill. 116

This verse describes the ill-effects of malnutrition. Fortune either gives one a hungry stomach and no food, which is the case of the poor, or it offers a feast that takes away the appetite, which is the case of rich people who have plenty, but can't enjoy it.

\section{Love's Labor's Lost, Act IV, Scene III,}

To fast, to study, and to see no woman- 289

Flat treason 'gainst the kingly state of youth.

Say, can you fast? Your stomachs are too young,

And abstinence engenders maladies. 292

The disadvantages of fasting at a very young age that causes ailments has been described.

76. Antony and Cleopatra, Act II, Scene I,

Tie up the libertine in a field of feasts, 23

Keep his brain fuming. Epicurian cooks

Sharpen with cloyless sauce his appetite,

That sleep and feeding may prorogue his honour

Even till a Lethe'd dullness 27

Preoccupation with overeating keeps a person from thinking clearly. Increased appetite and sleep makes one forgetful and is thus harmful.

77. The Comedy of Errors, Act V, Scene I,

Thou say'st his meat was sauced with thy upbraidings; 73

Unquiet meals make ill digestions;" 74

In food, in sport, and life-preserving rest 83

To be disturbed, would mad or man or beast. 84

Disturbance during a meal can disrupt proper digestion and any man or animal would go insane (figuratively) if meals are disturbed.

\subsection{Drugs / Poisoning}

78. Henry The Fifth, Act III, Scene VI,

Let gallows gape for dog; let man go free, 42

And let not hemp his windpipe suffocate. 43

Hemp is cannabis (marijuana). Long-term consumption of marijuana is associated with an increased risk of some respiratory problems, including an increase in cough, sputum production, airway inflammation, and wheeze (airway obstruction) ${ }^{9}$.

\section{Hamlet, Act I, Scene V,}

Upon my secure hour thy uncle stole, 61

With juice of cursed hebona in a vial,

And in the porches of my ears did pour

The leperous distilment; whose effect

Holds such an enmity with blood of man

That swift as quicksilver it courses through

The natural gates and alleys of the body;

And with a sudden vigour it doth posset

And curd, like eager droppings into milk, The thin and wholesome blood. So did it mine; 
And a most instant tetter bark'd about,

Most lazarlike, and with vile and loathsome crust,

All my smooth body. 73

The poison Black henbane (BH) (Hyoscyamus niger) has been used as a medicine since last centuries and has been described in all traditional medicines. All part of BH including leaves, seeds and roots contain some alkaloids such as Hyoscyamine, Atropine, Tropane and Scopolamine. Severe intoxication is accompanied by hypertension, respiratory arrest, coma, convulsions and death ${ }^{2}$.

80. Antony and Cleopatra, Act 5, Scene II,

Caesar- If they had swallow'd poison 'twould appear 344

By external swelling; but she looks like sleep,

As she would catch another Antony

In her strong toil of grace.

Dolabella- Here on her breast

There is a vent of blood, and something blown;

The like is on her arm.

First Guard- This is an aspic's trail; and these fig leaves

Have slime upon them, such as th' aspic leaves

Upon the caves of Nile

Caesar- Most probable

That so she died; for her physician tells me

She hath pursu'd conclusions infinite of easy ways to die. 355

The physical change of swelling of the body following traditional poisoning is described here but is suppressed since Cleopatra was most likely bitten by a serpent whose venom produced severe paralysis, deep coma, absent brainstem reflexes and thus the body appeared to be relaxed as if in a state of sleep.

\section{Romeo and Juliet, Act V, Scene I,}

Let me have 59

A dram of poison, such soon-speeding gear

As will disperse itself through all the veins

That the life-weary taker may fall dead,

And that the trunk may be discharged of breath

As violently as hasty powder fired

Doth hurry from the fatal cannon's womb. 65

This verse desribes the effects of a rapidly acting poison that results in violent respiratory failure.

82. Othello, Act III, Scene III,

Not poppy nor mandragora, 327

Nor all the dropsy syrups of the world,

Shall ever medicine thee to that sweet sleep 329

Mandrake (mandragora), a relative of Atropa belladonna contains hyoscyamine and atropine, and is known to be hallucinogenic, narcotic, emetic and purgative, and the verse states that no drug can cause as effective and deathly sleep like it.

2.20 Epilepsy

83. The Tempest, Act II, Scene II,

He's in his fit now, and does not talk after the wisest. 74

He shall taste of my bottle; if he have never drunk wine afore, it will 
go near to remove his fit. If I can recover him, and keep him tame, I

will not take too much for him 78

Alcohol (CNS depressant) as a treatment of a debilitating seizure is described here.

84. Othello, Act IV, Scene I,

Iago- My lord is fall'n into an epilepsy. 51

This is his second fit; he had one yesterday.

Cassio- Rub him about the temples.

Iago- No, forbear.

The lethargy must have his quiet course;

If not, he foams at the mouth, and by and by

Breaks out to savage madness. Look, he stirs.

Do you withdraw yourself a little while;

He will recover straight; when he is gone 58

The verse describes the clinical features of grand mal epilepsy.

85. Othello, Act V, Scene II,

And yet I fear you; for you're fatal then 36

When your eyes roll so. 37 and continues

Alas why gnaw you so your nether lip? 43

Some bloody passion shakes your very frame. 44

Features of lip-biting and violent shaking during a seizure has been described.

86. Julius Caesar, Act I, Scene II,

And when the fit was on him I did mark 120

How he did shake: 'tis true, this god did shake.

His coward lips did from their color fly,

And that same eye, whose bend doth awe the world,

Did lose his luster: I did hear him groan: 124

Clinical features of a seizure are stated.

87. Julius Caesar, Act I, Scene II,

Cassius- But soft, I pray you; what, did Caesar swoond? 249

Casca- He fell down in the market place, and foamed

At mouth, and was speechless.

Brutus- 'Tis very like he hath the falling sickness. 252

Clinical features of Tonic-clonic (Grand mal) seizures have been described.

88. King Henry, The Fourth, Part Two, Act IV, Scene IV,

King- And now my sight fails, and my brain is giddy. 110

O me! Come near me. Now I am much ill. 111

Warwick- Be patient, princes. You do know these fits 114

Are with his highness very ordinary.

Stand from him, give him air, he'll straight be well. 116

Fits that are self-limiting in their manifestation are described.

2.21 Ethics

89. All's Well That Ends Well, Act II, Scene I, 
When our most learned doctors leave us, and 119

The congregated College have concluded

That laboring art can never ransom nature

From her inaidable estate. I say we must not

So stain our judgment or corrupt our hope,

To prostitute our past-cure malady

To empirics, or to dissever so

Our great self and our credit, to esteem

A senseless help, when help past sense we deem. 127

Not to cast aside judgement, or overreach hope to offer up incurable sickness to quacks, or to divide one's selfrespect and reputation, and to pursue an impossible cure when called, are the ardent qualities of ethics of the profession.

90. Timon of Athens, Act IV, Scene III,

For there is boundless theft 428

In limited professions. Rascal thieves,

Here's gold. Go, suck the subtle blood o' th' grape,

Till the high fever seethe your blood to froth,

And so 'scape hanging. Trust not the physician;

His antidotes are poison, and he slays

Moe than you rob. Take wealth and lives together'

Do, villain, do, since you protest to do't. 435

The unethical practices of doctors have been alluded to in this verse which tells not to trust the doctor, because his cures are poisonous and he kills men even more often than thieves rob them, taking both money and lives.

91. Macbeth, Act IV, Scene III,

There are a crew of wretched souls 141

That stay his cure: their malady convinces

The great assay of art; but at his touch,

Such sanctity hath heaven given his hand,

They presently amend. 144

The wretched sick wait for the doctor to heal them. Their illness doesn't respond to the efforts of medicine, but when he touches them, they are healed. Shows the effect of compassion and empathy.

92. Macbeth, Act IV, Scene III,

How he solicits heaven, 149

Himself best knows: but strangely visited people,

All swollen and ulcerous, pitiful to the eye,

The mere despair of surgery, he cures, 152

And sundry blessings hang about his throne 158

That speak him full of grace. 159

The ability to cure people afflicted with a strange disease of swollen and ulcerous lesions that are pitiful to look at, and beyond the help of surgery, with compassion and prayer.

2.22 Fever

93. The Comedy of Errors, Act V, Scene I,

Thereof the raging fire of fever bred- 75

And what's a fever but a fit of madness? 76 
The relationship of very high fever with convulsions and delirium is stated here.

94. King John, Act V, Scene III,

Ay me! This tyrant fever burns me up, 14 and continues,

Weakness possesseth me, and I am faint. 17

High fever is related to physical weakness and clouding of the mind (delirium).

95. Troilus and Cressida, Act I, Scene III,

Exampled by the first pace that is sick 132

Of his superior, grows on an envious fever

Of pale and bloodless emulation;

And 'tis this fever that keeps troy on foot,

Not her own sinews. 135

A figurative description of lack of respect and command is compared to the paleness associated with fever that takes the power out of the muscles.

\section{$2.23 \underline{\text { Halitosis }}$}

96. A Midsummer Nights Dream, Act IV, Scene I,

And most 40

dear actors, eat no onions nor garlic, for we are to utter sweet breath, 41

Reference to bad breath is made here.

97. Much Ado About Nothing, Act II, Scene I,

If her breath were as terrible as her terminations, 240

there were no living near her; she would infect to the North Star. 241

The repulsiveness of bad breath is stated here.

98. Much Ado About Nothing, Act V, Scene II,

Foul words is but foul wind, and foul wind 52

Is but foul breath, and foul breath is but noisome. There-

fore I will depart unkissed. 54

Foul breath being nauseating and repulsive deters one from kissing.

99. Antony and Cleopatra, Act V, Scene II,

In their thick breaths, 211

Rank of gross diet, shall we be enclouded,

And forced to drink their vapour. 213

Halitosis occurs from eating unwholesome foods.

\subsection{Hypertension}

100. Love's Labor's Lost, Act IV, Scene III, (Blood-letting)

A fever in your blood? Why, then incision 94

Would let her out in saucers. Sweet misprision. 95

The reference to blood-letting as the treatment of hypertension is described.

101. King Richard The Second, Act 1, Scene I, (Possible cure by diuresis)

Let's purge this choler without letting blood 153

This we prescribe, though no physician;

Deep malice makes too deep incision. 155

The verse states the futility of blood-letting in conditions that arise from hatred and malice.

\subsection{Infections}


102. Coriolanus, Act III, Scene I,

Sicinius- He's a disease that must be cut away 294

Menenius- O, he's a limb that has but a disease;

Mortal, to cut it off; to cure it easy. 296

Menenius- The service of the foot once gangrened, is not then respected

For what before it was.

Brutus- We'll hear no more

Pursue him to his house and pluck him thence,

Lest his infection, being of catching nature,

Spread further. 309

The features of the seriousness of infective (gas) gangrene is being alluded to here and amputation is being suggested.

103. Hamlet, Act III, Scene IV,

It will but skin and film the ulcerous place 148

Whiles rank corruption, mining all within,

Infects unseen. 149

Reference here is to the fact that while infection persists, there is no use of applying a bandage for the infection would spread.

104. King Lear, Act II, Scene IV,

Thou art a boil, 220

A plague-sore, or embossed carbuncle

In my corrupted blood. 222

The reference is to the seriousness of a skin infection (abscess, carbuncle) spreading in the body and infecting it (septicemia).

105. Richard III, Act I, Scene III

O Buckingham, take heed of yonder dog, 288

Look when he fawns he bites; and when he bites

His venom tooth will rankle to death.

Have not to do with him, beware of him.

Sin, death, and hell have set their marks on him

And all their ministers attend to him. 293

The figurative description of lethality of a rabid dog's bite has been stated here.

106. King John, Act III, Scene III

But now will canker-sorrow eat my bud, 87

And chase the native beauty from his cheek, 88

And he will look as hollow as a ghost, 89

As dim and meagre as an ague's fit." 90

Canker indicates oral sores and the facial appearance as a result of this affliction has been compared to the pale look of a person suffering a shivering attack of malaria (ague's fit).

107. Coriolanus, Act I, Scene IV,

Boils and plagues 41

Plaster you o'er, that you may be abhorr'd 42

Further than seen and one infect another 43 
Against the wind a mile! 44

The widespread affliction with furuncles (skin absessess), disfiguraing of the body and its contagious.nature have been stated here.

\subsection{Madness / Depression / Schizophrenia}

108. Hamlet, Act III, Scene I,

Polonius - My lord, do as you please. 182

But, if you hold it fit, after the play

Let his queen mother all alone entreat him to show his grief. Let her be round

with him,

And I'll be placed, so please you, in the ear

Of all their conference. If she find him not,

To England send him or confine him where

Your wisdom best shall think.

Claudius - Madness in great ones must not unwatched go. 190

Depression requires gentle care and this is being alluded to.

109. The Merry Wives of Windsor, Act IV, Scene II,

Mrs. Page- Why, woman, your husband is in his old 19

lunes again. He so takes on yonder with my husband,

so rails against all married mankind, so curses all Eve's

daughters-of what complexion soever, and so buffets

himself on the forehead, crying, "Peer out, peer

out!" that any madness I ever yet beheld seemed but

tameness, civility, and patience to this his distemper

he is in now. I am glad the fat knight is not here.

Mrs. Ford- Why, does he talk of him?

Mrs. Page- Of none but him; and swears he was

Carried out, the last time he searched for him, in a

basket; protests to my husband he is now here, and

hath drawn him and the rest of their company from

their sport to make another experiment of his suspicion. 32

The craziness, rants and raves, the curses, being physically violent to oneself, are all signs of deranged behavior (schizophrenia).

110. The Merchant of Venice, Act I, Scene II,

In truth, I know it is a sin to be a mocker, 55

but he! Why, he hath a horse better than the Nea-

politan's, a better bad habit of frowning than the

Count palatine; he is every man in no man. If a

throstle sings, he falls straight a-cap'ring; he will fence

with his own shadow. If I should marry him, I

should marry twenty husbands. 61

Imitating qualities suggest no notable character in a person. If a bird sings, he starts dancing too, and shows off his fencing moves against his own shadow. These are all signs of a psychotic personality and thus such a person cannot be trusted. 
111. Richard III. Act I. Scene 1,

Why, I, in this weak piping time of peace, 26

Have no delight to pass away the time, 27

Unless to spy my shadow in the sun 28

And descant on mine own deformity: 29

And therefore, since I cannot prove a lover, 30

To entertain these fair well-spoken days, 31

I am determined to prove a villain 32

And hate the idle pleasures of these days. 33

Plots have I laid, inductions dangerous, 34

By drunken prophecies, libels and dreams. 35

The verse describes an altered mental status and personality (psychosis) developed from sheer hate and envy from one's own physical deformity whereby the person plans to harm others.

112. Twelfth Night, Act I, Scene III, (related to Creujfeld-Jacob disease!)

But I am a great eater of beef, and I believe that does 83

harm to my wit. 84

This is a surprising description of the mental state associated with the consumption of beef. Other than draw a relationship of beef consumption to indigestion as a cause for sickness, one cannot but think of the unique coincidence to Creujfeld-Jacob disease/Bovine spongiform encephalitis (Mad cow disease).

\subsection{Palpitation}

113. The Winter's Tale, Act I, Scene II,

I have tremor cordis on me; my heart dances, 110

But not for joy, not joy. This entertainment

May a free face put on, derive a liberty

From heartiness, from bounty, fertile bosom,

And well become the agent- 'may, I grant 114

Palpitation has been described as cardiac "tremor" at rest which is unrelated to excitement, physical activity and pregnancy, all of which are in context, related to a state of hyperdynamic circulation.

\subsection{Parkinsonism}

114. The Tempest, Act IV, Scene I,

Go charge my goblins that they grind their joints 258

With dry convulsions, shortens up their sinews

With aged cramps, and more pinch-spotted make them

Than pard or cat o' mountain 261

The reference here is to violent tremors akin to Parkinsonism from mortal fear in this case, and the effects including skin changes are stated.

115. Troilus and Cressida, ActI, Scene III,

And then forsooth, the faint defects of age 172

Must be the scene of mirth; to cough and spit,

And with a palsy fumbling on his gorget,

Shake in and out the rivet. 174

Senile neurodegenerative disorder of Parkinsonism has been stated.

116. Henry VI, Part II, Act IV Scene VII,

Dick- Why dost thou quiver man? 93 
Say- The palsy, and not fear, provokes me.

Cade- Nay, he nods at us, as who should say, 'I'll be

even with you'. I'll see if his head will stand steadier

on a pole, or no: 97

In this case, a neurodegenerative disorder has been alluded to rather than fear being the cause for the tremor. Here, the tremor appears to be cerebellar in origin involving the head (titubation) as a distinctive feature.

\section{$2.29 \underline{\text { Skin }}$}

117. The Two Gentlemen of Verona, Act IV, Scene IV,

She hath been fairer, madam, than she is. 149

When she did think my master loved her well,

She, in my judgment, was as fair as you.

But since she did neglect her looking glass,

And threw her sun-expelling mask away,

The air hath starved the roses in her cheeks

And pinched the lily-tincture of her face,

And now she is become as black as I. 156

Reference is likely to be the ill-effects of sun burn on the unprotected facial skin in the cold climatic conditions of Italy that result in dry scaly skin with hyperpigmentation.

118. The Tempest, Act I, Scene II,

Caliban- With raven's feather from unwholesome fen 324

Drop on you both! A southwest blow on ye

And blister you all o'er! 326

Poison ivy, poison oak, and poison sumac are referred to as 'fen' that grow in wooded or marshy areas. The plants have a sticky, long-lasting oil called urushiol that causes itchy, blistering cutaneous rashes following contact.

119. Henry V, Act 3, 6.48

His face is all bubukles, and whelks and knobs"

Description of pustules and inflamed swellings.

\subsection{Somnambulism}

120. Macbeth, Act V, Scene I,

Since his majesty went into the 5

field, I have seen her rise from her bed, throw her

nightgown upon her, unlock her closet, take forth

paper, fold it, write upon't, read it, afterwards seal it,

again return to bed; yet all this while in a most

fast sleep. 9

Features that are pathognomonic of somnambulism are described here.

121. The Tempest, Act II, Scene I,

It is a sleepy language, and thou speak'st 215

Out of thy sleep. What is it thou didst say?

This is a strange repose, to be asleep

With eyes wide open; standing, speaking, moving,

And yet so fast asleep. 218

The specific features of standing, speaking, and moving, with eyes wide open, and yet in a state of deep sleep are 
features seen in the state of somnambulism.

\subsection{Sympathetic activity}

122. King Henry The Fifth, Act III, Scene I,

But when the blast of war blows in our ears, 5

Then imitate the action of the tiger:

Stiffen the sinews, conjure up the blood,

Disguise fair nature with hard-favour'd rage;

Then lend the eye a terrible aspect:

Let it pry through the portage of the head

Like the brass cannon; let the brow o'erwhelm it" 11

"Now set the teeth, and stretch the nostril wide, 15

Hold hard the breath, and bend up every spirit

To his full height! 17

'Fight and flight' response acting on different systems have been stated in relative detail

123. Macbeth, Act I, Scene III,

If good, why do I yield to that suggestion 134

Whose horrid image doth unfix my hair

And make my seated heart knock at my ribs, 136

My thought, whose murder yet is but fantastical, 139

Shakes so my single state of man that function

Is smothered in surmise, and nothing is

But what is not. 142

Piloerection and palpitation are signs of sympathetic overactivity.

124. Macbeth, Act V, Scene III,

The devil damn thee black, thou cream-faced loon! 11

Where got'st thou that goose look? 12

Goose-flesh and paleness of the skin are signs of shock due to sympathetic response.

125. Hamlet, Act I, Scene V,

I could a tale unfold whose lightest word 15

Would harrow up thy soul, freeze up thy young blood,

Make thy two eyes like stars start from their spheres,

Thy knotted and combined locks to part,

And each particular hair to stand an end

Like quills upon the fearful porpentine. 20

Fear and panic result in sympathetic response causing pupillary dilatation and piloerection.

126. Hamlet, Act III, Scene IV,

Alas, how is't with you, 117

That you do bend your eye on vacancy,

Forth at your eyes your spirits widely peep,

And as the sleeping soldiers in th' alarm

Your bedded hair like life in excrements

Start up and stand an end. O gentle son, 
Upon the heat and flame of thy distemper

Sprinkle cool patience. 124

Similar effects to those stated in the previous verse are described here.

127. Much Ado About Nothing, Act IV, Scene I,

I have marked 157

A thousand blushing apparitions

To start into her face, a thousand innocent shames

In angel whiteness beat away those blushes,

And in her eye there appeared a fire

To burn the errors that these princes hold 162

The redness of the face is drained away with paleness due to sympathetic activity.

128. Cymbeline, Act III, Scene III,

The princely blood flows in his cheek, he sweats, 93

Strains his young nerves, and puts himself in posture 94

Preparation of the body for the 'fight and flight' response.

129. The Merchant of Venice, Act I, Scene II,

The brain may 17

devise laws for the blood, but a hot temper leaps o'er

a cold decree; such a hare is madness the youth to skip

o'er the meshes of good counsel the cripple. 20

The brain controls the sympathetic system that causes heated temperament that cripples wisdom.

\subsection{Syphilis}

130. Troilus and Cressida, Act V, Scene I,

Why, his masculine whore. Now the 18

rotten diseases of the south, the gut-ripping ruptures,

catarrhs, loads o' gravel in the back, lethargies, cold

bladders full of imposthume, sciaticas, lime-kilns i'

the palm, incurable bone-ache, and the riveled fee-

simple of the tetter, and the like, take and take again

such preposterous discoveries! 25

Reference to male gay sex and its association with syphilis with all its maladies are stated here.

131. Timon of Athens, Act IV, Scene III,

Be a whore still; they love thee not that use thee. 84

Give them diseases, leaving with thee their lust.

Make use of thy salt hours. Season the slaves

For tubs and baths; bring down rose-cheeked youth

To the tub-fast and the diet. 87

The cause of venereal disease is mentioned and the curing effect of diet and salt baths has been described.

132. Timon of Athens, Act IV, Scene III,

Consumptions sow 152

In hollow bones of man; strike their sharp shins,

And mar men's spurring. Crack the lawyer's voice, 
That he may never more false title plead,

Nor sound his quillets shrilly. Hoar the flamen,

That scolds against the quality of flesh

And not believes himself. Down with the nose,

Down with it flat, take the bridge away 159 and continues

Plague all, 163

That your activity may defeat and quell

The source of all erection. 165

Tertiary syphilis can affect multiple organ systems, including the brain, nerves, eyes, heart, blood vessels, liver, bones, and joints. On the face, it can cause destruction of the nasal bridge and flatten the nose. It can cause Stroke, Meningitis, Hearing loss, Visual problems, Dementia, Loss of pain and temperature sensations, Sexual dysfunction in men (impotence), Bladder incontinence, sudden lightning-like pains in bones. Syphilitic laryngitis is also a known entity.

\subsection{Ventricular hypertrophy}

133. King Lear, Act III, Scene VI,

Then let them anatomize Regan. See what 75

breeds about her heart. Is there any cause in nature

that make these hard hearts? 76

Causes of hardening of hearts is stated here. This appears to be an example of hypertrophy of cardiac muscle (hardening) as opposed to hypoplasia (softening).

\section{Conclusion}

Many of Shakespeare's medical references and imagery were important components of his writing style, and he used them more often than his contemporaries did at the time, and his genius was beyond that of any other bard and playwright in history. A study of Shakespeare's images of sickness shows that he had a distinct interest and acumen in describing medical conditions with accuracy, probity and incorporating clinical features both figuratively as well as succinctly through characters in his plays. It is unlikely that any other single author has been as thoroughly scrutinized as William Shakespeare, and this comprehensive work attempts to validate it further by drawing a parallel on modern day medical symptomatology, pathophysiology and management in light of Shakespeare's ingenious, immaculate and unmatched poetic brilliance.

Acknowledgement: Ms. Vengilyn Umali Garcia for typesetting the article.

\section{References}

1. Afshari NA, Afshari MA, Foster CS. (2001). Inflammatory conditions of the eye associated with rheumatic diseases. Curr Rheumatol Rep. Oct;3(5):453-8).

2. Anahita A, Mohammad M, Javad A, and Mahdi BM. Avicenna. (2014). Black henbane and its toxicity a descriptive review. J Phytomed. 2014 Sep-Oct; 4(5): 297-311.

3. Andreasen, N. The Artist as a Scientist. Psychiatric diagnosis in Shakespeare's tragedies. JAMA, (1976), 235: $1868-1872$

4. Chakravarty, M. Abu-Hijleh, MF. (2009). Neurological Symptoms and signs: Clinical Features in Shakespearean Plays. Pan Arab Medical Journal. 2009, Vol 2, No. 14, pp 22-25

5. Cummings, MJ. (2018). Bard Was Well Versed in Human Afflictions and Their Treatments.

Shakespeare and Medicine With a Glossary of Medical Terms.

http://www.shakespearestudyguide.com/Medicine.html

6. Fogan, L. (i989). The Neurology in Shakespeare. Arch. Neurol. 1989, 46, 922-924

7. Fu, KTL. (1998). The healing hand in literature: Shakespeare and surgery. HKMJ 1998;4:77-88

8. Goens, J., Gheeraert, P. Skin Diseases in Shakespeare's Works. Paper obtained from: 
http://www.chez.com/sfhd/ecrits/shakes.htm

9. Howden, ML, Naughton MT. (2011). Pulmonary effects of marijuana inhalation. Expert Review of Respiratory Medicine;5(1):87-92)

10. Kail, AC. (1983). The Bard and the Body.1. Shakespeare's Physicians, Med.J.Aust. 1983, Oct.1; 2(7): 338-344

11. Kail, AC. (1983).The Bard and the Body.2. Mental Illness. Med.J.Aust. 1983, 139:390-405

12. Kail, AC. (1986).The Medical Mind of Shakespeare, (William and Wilkins, Balgowlah, New South Wales), $\quad$ Extract from: http://www.farklempt.com/Articles/The\%20Fassenden\%20Re.../medmindofShakespeare.htm

13. Lienhard, JH. Engines of Our Ingenuity; Episode No. 1143; Obtained from Site: http://www.uh.edu/engines/epi1143.htm

14. Moss, ML (1965). Hypertyelorism and Cleft Palate deformity. Acta Anatomica, 1965, 61: 547-557

15. Owen, OW. The Medicine in Shakespeare. Extracts from a lecture at a stated meeting of the Detroit Medical and Library Association. Obtained from Site http://www.sirbacon.org/owencirculation.htm

16. Stearns, CW. (1865). Shakespeare's Medical Knowledge, 1865, Reprint Ist Edition, AMS Press Inc. New York, 1973. ISBN 0-404-06224-5. Text obtained from http://www.webincunabula.com/html/st/stearns_2.jpg

17. https://emedicine.medscape.com/article/1177523-overview. 